\title{
Color me healthy: Food diversity in school community gardens in two rapidly urbanizing Australian cities
}

\author{
Daniela A. Guitart ${ }^{1}$, Catherine M. Pickering ${ }^{2}$ and Jason Byrne ${ }^{* 3}$
}

\begin{abstract}
Community garden research has focused on social aspects of gardens, neglecting systematic analysis of what food is grown. Yet agro-diversity within community gardens may provide health benefits. Diverse fruit and vegetables provide nutritional benefits, including vitamins, minerals and phytochemicals. This paper reports research that investigated the agrobiodiversity of school-based community gardens in Brisbane and Gold Coast cities, Australia. Common motivations for establishing these gardens were education, health and environmental sustainability. The 26 gardens assessed contained 234 food plants, ranging from 7 to 132 plant types per garden. This included 142 fruits and vegetables. The nutritional diversity of fruits and vegetable plants was examined through a colour classification system. All gardens grew fruits and vegetables from at least four food colour groups, and $75 \%$ of the gardens grew plants from all seven colour groups. As places with high agro-diversity, and related nutritional diversity, some school community gardens can provide children with exposure to a healthy range of fruit and vegetables, with potential flow-on health benefits.
\end{abstract}

\section{Research highlights}

- Study area school gardens grow 234 different plant types (159 species \& 66 families)

- Diversity of school garden produce may improve student health via better nutrition

- Many schools use their gardens as part of their curriculum, including health classes

- Students cooked garden produce at school as part of the curriculum

- Garden fruit and vegetables were used in tuck shops, taken home and sold to staff

- Gardens were developed for education (91\%), health (44\%) and sustainability (40\%)

\section{Keywords}

Urban agriculture, nutrition, education, school gardens, community, health 


\section{Author affiliations}

1. Research Assistant, National Climate Change Adaptation Research Facility, Griffith University, Gold Coast Qld 4222 Australia. Phone: +61 (7) 5552 7547, Fax: +61 (7) 5552 7333, Email: d.guitart@griffith.edu.au.

2. Associate Professor, School of Environment, Environmental Futures Centre, Building G24, Room 3.08, Griffith University, Gold Coast campus, QLD 4222, Australia. Phone: +61 7 5552 8059, Fax: +61 75552 8067, Email: c.pickering@griffith.edu.au.

3. * Correspondence Author: Senior Lecturer, School of Environment, Environmental Futures Centre, Building G31, Room 3.06, Griffith University, Gold Coast campus, QLD 4222, Australia. Phone: +61 75552 7723, Fax: +61 75552 8244, Email: jason.byrne@griffith.edu.au. 


\section{Color me healthy: Food diversity in school community gardens in two rapidly urbanizing Australian cities}

\section{Introduction}

Researchers have found a close association between rapid urbanisation, green-space loss, and declining citizen health (Broadway and Broadway, 2011; Domene and Sauri, 2007; Groenewegen et al., 2006; Pauleit et al., 2005; Turner et al., 2011). Rapidly increasing urbanization is a major issue confronting many countries including Australia. Rapid urbanization typically results in the loss of viable agricultural land and in increasing separation of urban residents from food production (Eigenbrod et al., 2011; Wu et al., 2011). Urban residents are less likely to produce food or even see food being grown (Campbell, 2004; Clement, 2010; Zaradic et al., 2009). Weekly shopping trips to sanitized supermarkets with abundant, colorfully packaged foods are the closest that many city-people get to food production (Kameshiwari and Kaufman, 1999). One factor contributing to these problems has been changing food-production practices (Pothukuchi and Kaufman, 1999) and flow-on dietary and nutrition impacts.

Major changes in people's experience of growing food have been described by some as a ‘nutrition transition’ (Popkin, 1999). Such changes are associated with decreased general health in many urban populations, including dramatic increases in obesity - especially among children (Blair, 2009; Cameron et al., 2003; Somerset et al., 2005). Many urban dwellers, particularly children in the developed world, consume less fresh fruit and vegetables, eat more processed food, and are more sedentary than rural counterparts (Somerset et al., 2005). 
In some countries, children's intake of fast food has increased by $300 \%$ in two decades (Sanigorski et al., 2007). Australia is no exception; many Australians now eat fewer fruits and vegetables than is recommended for good health and have less contact with the natural world than did previous generations (Magarey et al., 2001; Timperio et al., 2008).

Statistics indicate that poor food choices are also contributing to obesity in Australia, with $60 \%$ of adults and $25 \%$ of children either overweight or obese (Australian Bureau of Statistics (ABS), 2009). Most Australians eat fewer fruits and vegetables than is recommended for good health. For example, 78\% of Australian children aged 4-8 years old and $86 \%$ aged 9-13 do not eat the daily-recommended amount of vegetables (Department of Health and Ageing, 2007). Obstacles preventing children from adopting healthy diets include: taste preferences, knowledge, availability, convenience, peer pressure and parental or school support (O'Dea, 2003).

Community gardens are seen as one way to counter some of these trends (Block et al., 2012). Research on community gardens has demonstrated clear linkages between gardening, improved levels of physical activity, and better nutrition (Armstrong, 2000; Harris, 2009, Kingsley et al., 2009; Tieg et al., 2009; Wakefield et al., 2007). School-based community gardens are an example. School-based community gardens (hereafter referred to as school gardens) are a subset of the broader community gardening movement (Graham et al., 2005; Henryks, 2011; Ozer, 2007; Somerset et al., 2005). Located on land used for the full spectrum of schools (K-12), they are a distinctive type of community garden (Birky and Strom, 2013). Such gardens can act as place-based health interventions, helping to transform students' 
eating habits and knowledge about food production (Lineberger and Zajicek, 2000; Ratcliffe et al., 2011). Such gardens can be considered to be a type of community garden because they: are community assets; benefit the wider community through knowledge acquisition and transmission and; have the potential to change people's access to safe and nutritious food at the neighborhood level (Chomitz et al, 2010). For example, researchers have reported that school children may educate their parents and siblings about lessons they have learned in the gardens and can sometimes take produce from the gardens back home to share with their families, thus altering wider eating habits (Heim et al., 2009; see also Heim et al., 2011).

School gardens can positively influence children's diets in various ways, including educating children about a wide variety of healthy and nutritious foods; knowledge that commentators suggest has been lost through the above mentioned changes in urban lifestyles. In school gardens, children can become more familiar with a diverse range of fruits and vegetables (Allen et al., 2008). Increasing familiarity and experiencing different foods is likely to enhance children's willingness to try new foods contributing to more nutritious diets. But we know very little about what plants are actually grown in school gardens, how diverse these gardens are, and the nutritional value of plants grown in these gardens.

This paper discusses research into school gardens in two cities within a rapidly urbanizing metropolitan region - Brisbane and Gold Coast cities, Australia. We begin by discussing the health benefits ascribed to community gardens, and then consider health benefits associated with eating a diversity of fruit and vegetables. We then examine the diversity of plants grown within all known school gardens in the study area (see methods section for details on how 
these were located), and their potential nutritional value, based on a nutritional color classification analysis. We also assess the motivations of garden managers for developing these gardens, to establish the extent to which health benefits may be driving garden development. We conclude by recommending directions for future research.

\section{Health benefits of community gardens}

Much of the literature suggests that community gardens confer multiple health benefits upon their users (Alaimo et al., 2008; Armstrong, 2000). Many international studies have explored the link between the active lifestyles and healthier diets of community gardeners and the potential for community gardens to combat obesity, heart disease and several types of cancer (e.g. Armstrong, 2000; Wakefield et al., 2007). Community gardening has been shown to confer both physical and mental health benefits on gardeners (Kaplan, 1973; Somerset et al., 2005; Wakefield et al., 2007; Kingsley et al., 2009). Community gardeners have been found to consume more fresh fruits and vegetables and less sweet foods and drinks, compared with non-gardeners (Blair et al., 1991). Studies have also pointed to the health benefits of school gardens (see Blair et al., 1991; Somerset et al., 2005; Morris and Zidenberg-Cherr, 2002; Graham et al., 2005; McAleese and Rankin, 2007).

School gardens could be a useful education tool for improving children's dietary behavior and improving access to a diversity of healthful food (Blair et al., 1991; Corkery, 2004; Somerset et al., 2005). School gardens are a form of urban agriculture where children produce their own food while learning about where food comes from, food nutrition, and healthy cooking (Blair, 2009; Canaris, 1995; Morris and Zidenberg-Cherr, 2002; Somerset et 
al., 2005). In Australia such gardens are receiving widespread support, with organizations such as the Stephanie Alexander Kitchen Garden Foundation providing skills, resources and guidance to schools to assist them in establishing community gardens (Block et al., 2012). Despite research about perceived health and education benefits of school community gardens, very little research has evaluated the actual agro-biodiversity within these gardens, and potential health benefits for children. In other words, what different types of fruit and vegetables are grown, and do these plants provide a diversity of vitamins, minerals and phytochemicals that may have positive health benefits for children? This paper seeks to address that knowledge gap.

\section{Health benefits of fruit and vegetable consumption}

Increased consumption of fruits and vegetables is associated with a noticeable decrease in the risk of diseases such as cardiovascular diseases, cancer and type 2 diabetes (Heber and Bowerman, 2001; Jamison, 2003; Perrin et al., 2002; Somerset et al., 2005; Stables et al., 2002). In addition to consuming more fruit and vegetables, nutritionists have found that it is important to consume a wide diversity of these food-types, as different foods contain different vitamins, minerals and phytochemicals (Vaughan and Geissler, 2009). Phytochemicals for example, can alter gene expression to restrain carcinogenesis via different pathways (Jamison, 2003). Researchers have suggested that because many phytochemicals have distinct colors, a color code system for classifying and analyzing the beneficial properties of fruit and vegetables could be used as an effective intervention to promote dietary diversity for optimal health (Heber and Bowerman, 2001). 
Examples of phytochemicals associated with particularly colors and food include the reds in tomatoes which are due to the presence of lycopene which is associated with prostate health. Strawberries, blueberries and grapes (red, blue and purple foods) contain anthocyanins and polyphenols, which are powerful antioxidants. Avocadoes and honeydew melons (light green foods) are rich in lutein and zexanthin, which are found in the retina where age-related macular degeneration occurs (Heber and Bowerman, 2001). Broccoli and kale (dark green foods) contain glucosinolates, which have been associated to reducing risk of cancer, particularly lung and gastrointestinal tract (Lund, 2003). Orange foods (carrots and mangoes) contain carotenoids which can enhance the immune system, whereas peaches and oranges (orange-yellow foods) contain cryptoxanthin and flavonoids which induce human protective enzyme systems (Yao et al., 2004). Finally, leeks, garlics and onions (white-green foods) contain allyl sulphides which are have antibacterial properties and detoxify carcinogens (Van Duyn and Pivonka, 2000). Eating at least one serving of fruit and/or vegetable from each of these color groups daily ensures a good spectrum of phytochemicals, along with vitamins and minerals are consumed, thus improving a range of potential health outcomes (Heber and Bowerman, 2001; Jamison, 2003).

In the remainder of this paper we examine the plant types grown in community gardens within two of Australia's fastest growing cities: Brisbane and Gold Coast. This research included assessing school gardens based on their size and motivations for their establishment, as well as what was grown. Food diversity was assessed in relation to the spectrum of colors represented by the fruit and vegetables grown, to determine if these gardens likely contribute to children's experience of, and potential consumption of, diverse beneficial food plants. 


\section{Study area}

Brisbane and Gold Coast cities in South East Queensland, Australia, now face the twin-crises of declining natural areas and unhealthier populations, which tend to accompany rapid urbanization (Byrne et al., 2010). These cities were selected based on three criteria: (i) they are rapidly growing; (ii) they contain many community gardens, including school gardens and; (iii) they are located on some of the Australia's most fertile land (Hutcheon, 2011), with a warm subtropical climate that allows vegetables to be grown year round (Kottek et al., 2006). Brisbane City is Australia's third most populous city, and the capital of the State of Queensland. It covers approximately $1,142 \mathrm{~km}^{2}$ and has a population of 2,043,185 (ABS, 2011). Gold Coast City, $80 \mathrm{~km}$ south of Brisbane, covers approximately $414 \mathrm{~km}^{2}$ with a population of 527,828 (ABS, 2011) and is Australia's sixth largest city (see Figure 1). There are 566 state schools and 92 private schools in Brisbane and 116 state schools and 39 private schools on the Gold Coast.

Rapid urbanization in South East Queensland, where these two cities are located, is reconfiguring the general 'food environment' to which residents including school children are exposed. Larder et al. (2012) have shown for example how food insecurity is increasing in South East Queensland. Moreover, Pires and Burton (2013) have recently reported that there are increasing constraints to growing fresh food in the region. Community gardens, including school gardens, are one of the few places where people living in medium to higher density built environments in South East Queensland (with reduced access to backyards) can grow their own food. 
Unlike some cities in the United States, access to different types of food in South East Queensland does not seem to be configured by social disadvantage or residential density. But overweight and obesity are increasing problems. Data from the Queensland Government shows that a third of Queensland adults are overweight and a fifth are obese (Queensland Government, 2011). Further, over a quarter of Queensland children are overweight or obese. As shown in the literature, school community gardens may have a role to play in combating these problems. As a step towards better understanding the role of these gardens in fostering health, this paper assesses the nutritional value of food grown in school gardens.

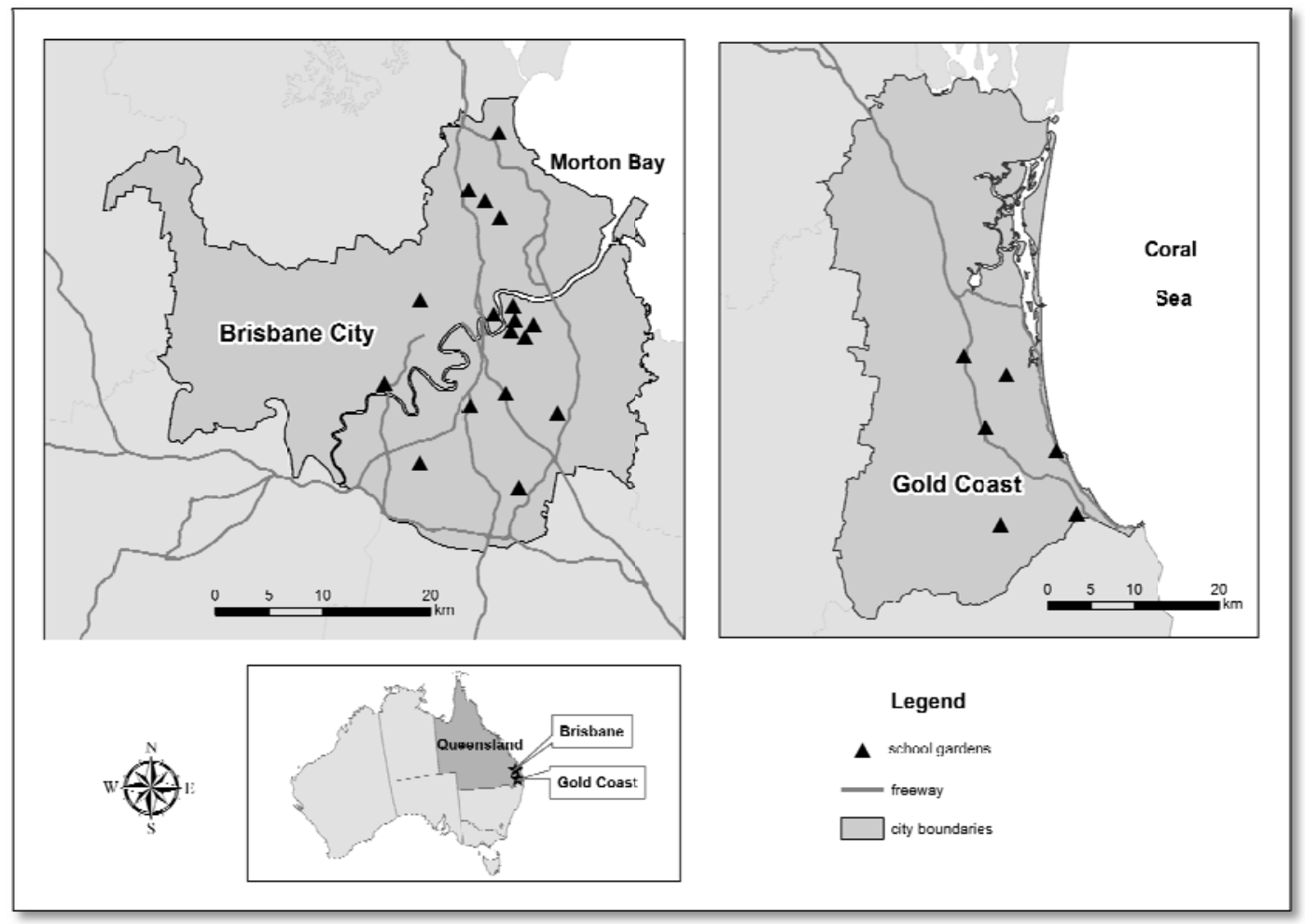

Figure 1 Location of school community gardens in Brisbane and Gold Coast. 


\section{Methods}

We compiled a comprehensive list of all school gardens in the study area by searching online community garden databases and conducting general web searches. We cross-validated our findings against municipal inventories, the Kitchen Garden Foundation (2013) school database and against school websites. We then interviewed local government officers and garden coordinators. In total, 26 school gardens were identified across Gold Coast and Brisbane cities. During an initial telephone contact, we asked garden managers (the person in charge of the garden such as, garden specialist, grounds person or teacher) whether they were willing to participate in the research and general information about the structure of the gardens (e.g. who participates, when, what is done with the produce, etc.), as well as if they knew of any other school gardens within the study area. Managers of three gardens were unwilling to participate in the study, as they did not have sufficient time. Our sample is, therefore comprised of 23 school gardens across Brisbane and Gold Coast cities (see Figures $1 \& 2)$.

Garden managers were surveyed on-site, to obtain quantitative data about what was grown in the gardens. The home institution's human ethics research committee approved the survey instrument (ENV/12/11/HREC). In late 2013, we followed up with garden managers to verify four further questions: (i) Is the food grown in your garden used in your school tuck shop?; (ii) Can students take the food grown in the garden home to eat?; (iii) Does your school teach about food and nutrition as part of the curriculum?; (iv) Is the school garden used as part of teaching that curriculum? To assess food options for students and their families at these schools we also calculated the shortest distance from the school to different food choices, including fast food outlets, supermarkets and farmers markets. 
When collecting information about the plants in the gardens, data was collected about the types of plants grown rather than species, because one species can produce a range of different types of foods, and gardeners are often more familiar with common names for plant types rather than their scientific names. For example, few gardeners could be expected to know that the species Brassica oleracea has various forms including cabbage, kale, turnip, swede, pak choi and kohlrabi (Vaughan and Geissler, 2009). Similarly, data was not collected at the level of plant varieties as gardeners may be unfamiliar with the correct variety name for the plants they grow, and may use a single name for several different varieties. Instead the common terminology used in books such as 'The New Oxford Book of Food Plants' and other books about gardening in warm climates (Blazey and Varkulevicius, 2006; McFarlane, 2008; Oakman, 1975; Vaughan and Geissler, 2009) were used to create a list of 347 possible plant types that could be grown in community gardens in the study area. This included plants grown for food as well as other common non-edible garden plants. Plant types were categorized by their most common use (e.g. fruit, vegetable, herb, nut, grain, flower). Managers were asked to record each type of plant currently in the garden and/or grown in during the previous 12 months. An open-ended question was included to allow managers to add any plants not already on the list we provided.

Other information obtained included how long the garden had been established and the motivation of managers for developing the garden. The area of each garden was obtained using a Trimble Juno ${ }^{\mathrm{TM}}$ hand held GPS. Additional information about the food plants was gathered from published literature and added to our database, including: the species, family, and primary use - and for all fruit and vegetables their color code, according to a 
phytochemical classification system for promoting the consumption of a diversity of foods (Heber and Bowerman, 2001).

All information gathered from the garden manager surveys was entered into a Microsoft Excel database. Data was transferred to SPSS statistical package for analysis. To examine if the size of gardens varied with when they were established, Pearsons correlation co-efficients were calculated for age and garden size versus plant type diversity. One-way ANOVAs were performed to compare plant type diversity among gardens with different motivations.

\section{Results}

Only one of the schools was private, the rest were publicly-owned schools run by the Queensland Government Department of Education. Nonetheless, most schools were located in areas with medium density and all but 3 of the schools were located in areas of relatively high social advantage, as identified by the Australian Census. The Australian Bureau of Statistics' (2013) index of disadvantage - socio-economic index for areas (SEIFA), is a standardized, weighted distribution of socio-economic measures that highlight social vulnerability (e.g. renting, single-parent, low-income, low education attainment etc.) within census areas. The lower the SEIFA score, the higher the relative disadvantage. A score of 1-2 for example indicates very high disadvantage whereas a score of 9-10 indicates the opposite. According to 2011 census data, just 1 school garden was located in an area of high social disadvantage, 2 schools were in areas of moderate disadvantage, 6 schools in areas that were neutral (neither high nor low) and the remainder (14 schools) were located in areas with high social advantage (e.g. high levels of affluence). There was no relationship between school 
location and density. Just over half the schools (13) were located in areas with low or medium density (ranging between 60 persons per $\mathrm{km}^{2}$ and 1,826 per $\mathrm{km}^{2}$ ) and the balance (10) were in areas of high $\left(2,077-2,759\right.$ persons per $\left.\mathrm{km}^{2}\right)$ or very high density $(3,056-5,862$ persons per $\mathrm{km}^{2}$ ).

Most gardens were new, with $80 \%$ of them established since 2008; the oldest was established in 1991. Gardens ranged in size from $7 \mathrm{~m}^{2}$ to $3080 \mathrm{~m}^{2}$, averaging $646( \pm 152) \mathrm{m}^{2}$. School garden managers listed between one and five motivations for establishing the gardens. The most common motivation was education (91\%) followed by increasing health (44\%) and contributing to environmental sustainability (40\%). These motivations for establishing and operating community gardens in schools in Brisbane and the Gold Coast were similar to other school gardens, where gardens are used to teach science, environmental studies, and nutrition and in many instances are part of the school curriculum (Blair, 2009; Graham et al., 2005; Somerset et al., 2005). Seven school gardens in the current study were supported by the Stephanie Alexander Kitchen Garden Foundation, an Australian organization founded by Stephanie Alexander, a well known and published cook, to introduce food education into schools (Kitchen Garden Foundation, 2013).

In Brisbane, almost half the school gardens (47\%) had a supermarket within easy walking distance (less than 800 meters) and just over half had one within easy cycling distance (less than $3 \mathrm{~km}$ ). On the Gold Coast, two-thirds of the school gardens had a supermarket within walking distance. Similarly, in Brisbane just over half (52\%) of the school gardens had a fast food store within cycling distance; half of the Gold Coast gardens had one within walking 
distance. In both cities, most school gardens had a farmers market only within driving distance (greater than $3 \mathrm{~km}$ ) (Table 1). A wide range of foods were thus available to students and their families.

Table 1. Characteristics of the food environment around 26 schools with gardens. Data is the shortest distance for different types of food options from the schools.

\begin{tabular}{|c|c|c|c|c|c|c|}
\hline \multirow{2}{*}{$\begin{array}{l}\text { Distances } \\
\text { to nearest... (m) }\end{array}$} & \multicolumn{2}{|c|}{ Fast-food outlet } & \multicolumn{2}{|c|}{ Supermarket } & \multicolumn{2}{|c|}{ Farmers market } \\
\hline & $\mathbf{n}$ & $\%$ & $\mathbf{n}$ & $\%$ & $\mathbf{n}$ & $\%$ \\
\hline 0-499 meters & 4 & 17.4 & 4 & 17.4 & 2 & 8.7 \\
\hline 500 to 999 & 6 & 26.1 & 8 & 34.8 & & \\
\hline 1000 to 1499 & 5 & 21.7 & 6 & 26.1 & & \\
\hline 1500 to 1999 & 4 & 17.4 & 4 & 17.4 & & \\
\hline 2000 to 2499 & 2 & 8.7 & & & 2 & 8.7 \\
\hline 2599 to 2999 & & & & & 3 & 13.0 \\
\hline 3000 to 4999 & 1 & 4.3 & & & 7 & 30.4 \\
\hline 5000 to 9999 & & & & & 7 & 30.4 \\
\hline $10000+$ & 1 & 4.3 & & & 2 & 8.7 \\
\hline
\end{tabular}

NOTE: 1 = Walking distance is less than $800 \mathrm{~m}$, cycling distance is less than $3 \mathrm{~km}$, and driving distance is more than $3 \mathrm{~km}$.

Based on follow-up contact with the schools, we found that just over half of the responding schools (52.4\%) sold their produce in their tuckshop (lunch-bars), and almost all of them (95.4\%) used the produce in class for educational purposes. Generally, children would have one gardening class and one cooking class weekly, and more than a third of the schools (40\%) used garden produce in these cooking classes. In other instances, the gardens or produce from the gardens would also be used for other subjects such as science or mathematics (see Table 2). Two-thirds of surveyed schools (66.6\%) allowed students to take produce grown in the gardens home to share with their families. Almost half of responding schools $(47.6 \%)$ generated a surplus from their gardens beyond their needs, and a quarter of the schools sold 
some of that surplus to staff, to generate revenue for ongoing garden maintenance (see Table 2).

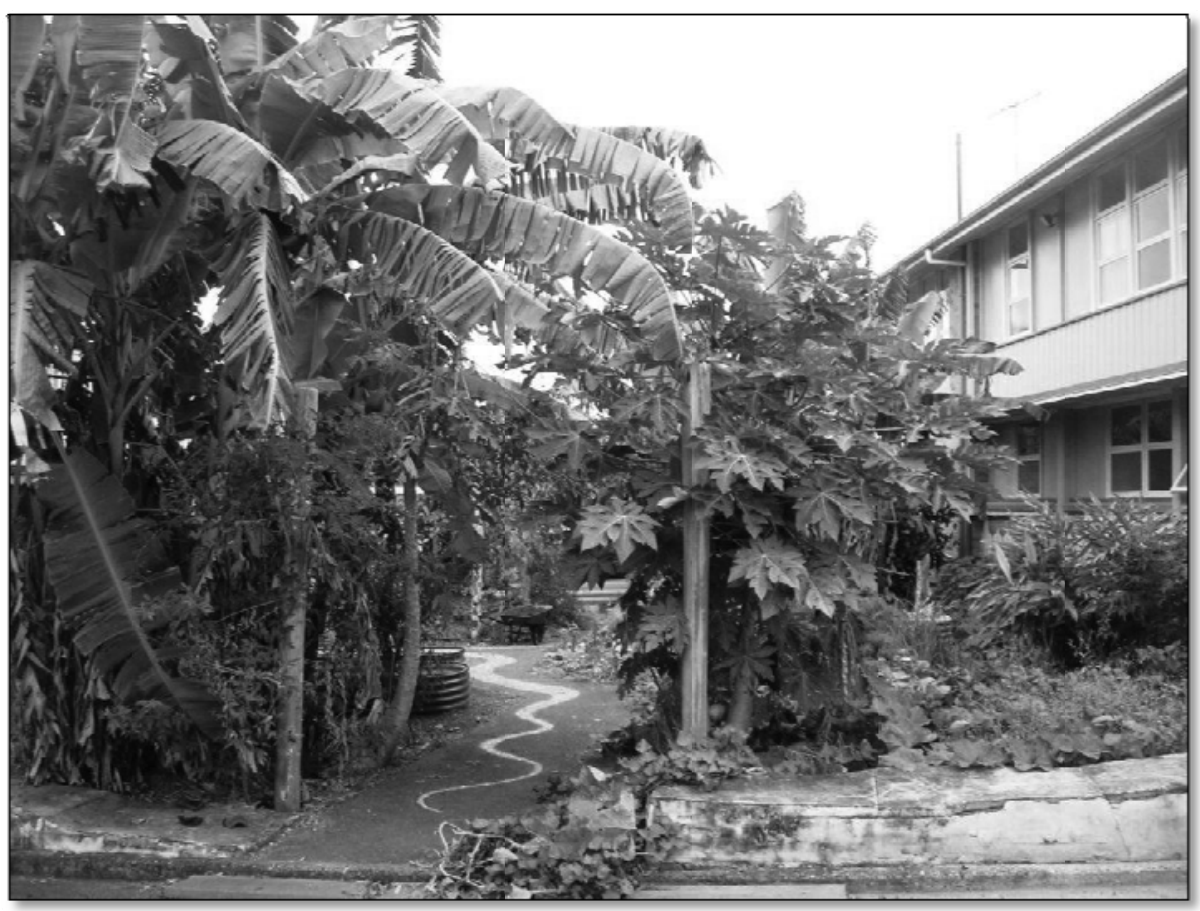

Figure 2 A school community garden in Brisbane.

A total of 234 different types of plants were grown across the 23 school gardens, representing at least 159 species and 66 families. Many plants came from three families: the Fabaceae, with 20 types of plants (e.g. peas and beans), the Brassicaceae, with 19 types of plants (e.g. rocket, broccoli, radish, cabbage, etc.), and the Asteraceae, with 18 types of plants (e.g. lettuce, tarragon, endive, dandelion, artichoke, etc.). Plants were predominately herbs (43\%) or trees $(22 \%)$, with few vines $(15 \%)$, shrubs $(11 \%)$ or grasses $(7 \%)$. More plants were perennials (57\%) than annuals (16\%), while $20 \%$ of the plants can be grown as annuals or perennials depending on conditions. Plants grown included: vegetables (33.5\%), fruits 
(27.5\%) and herbs (26.5\%), and a few flowers (5.5\%), grains (5\%) and nuts (2\%). Of all these, $12 \%$ were Australian native food plants (i.e. bush tucker) including: Davidson plum, finger lime, lemon myrtle, desert fig, bush banana and bush plum. On average $63( \pm 8)$ different plant types were grown per garden, however there was a large range, with the most diverse garden growing 139 different plant types and the least diverse growing seven types of plants. On average the gardens grew $15( \pm 2)$ types of fruits and $26( \pm 3)$ types of vegetables. The diversity of fruits and vegetables grown was not correlated with the age of the garden ( $\mathrm{r}$ $=0.291, \mathrm{p}=0.178$ ) nor its size (Persons correlation co-efficient, $\mathrm{r}=0.078, \mathrm{p}=0.723$ ). There was no significant difference in the number of fruits and vegetables grown between schools motivated by health promotion and those that were not (One-Way ANOVA, $\mathrm{F}=2.012, \mathrm{p}=$ $0.171)$.

The most common fruits and vegetables grown included: tomato, lettuce, pumpkin, cucumber, passion fruit, rocket, strawberry and paw paw (papayas), which were grown in over three quarters of the gardens. Over half of the gardens grew orange, carrot, potato, broccoli, lemon, pak-choi, peas, sweet potato, garlic, beetroot, eggplant, radish, broad beans and capsicum (bell peppers). When assessed in relation to the color code system for classifying the beneficial properties of fruit and vegetables (Heber and Bowerman, 2001) these 22 most common fruits and vegetables covered all the different nutritional colors (see Figure 3). Three quarters of the gardens grew fruits and vegetables from all seven color categories, and the remaining 25\% growing at least from 4 different colors. 


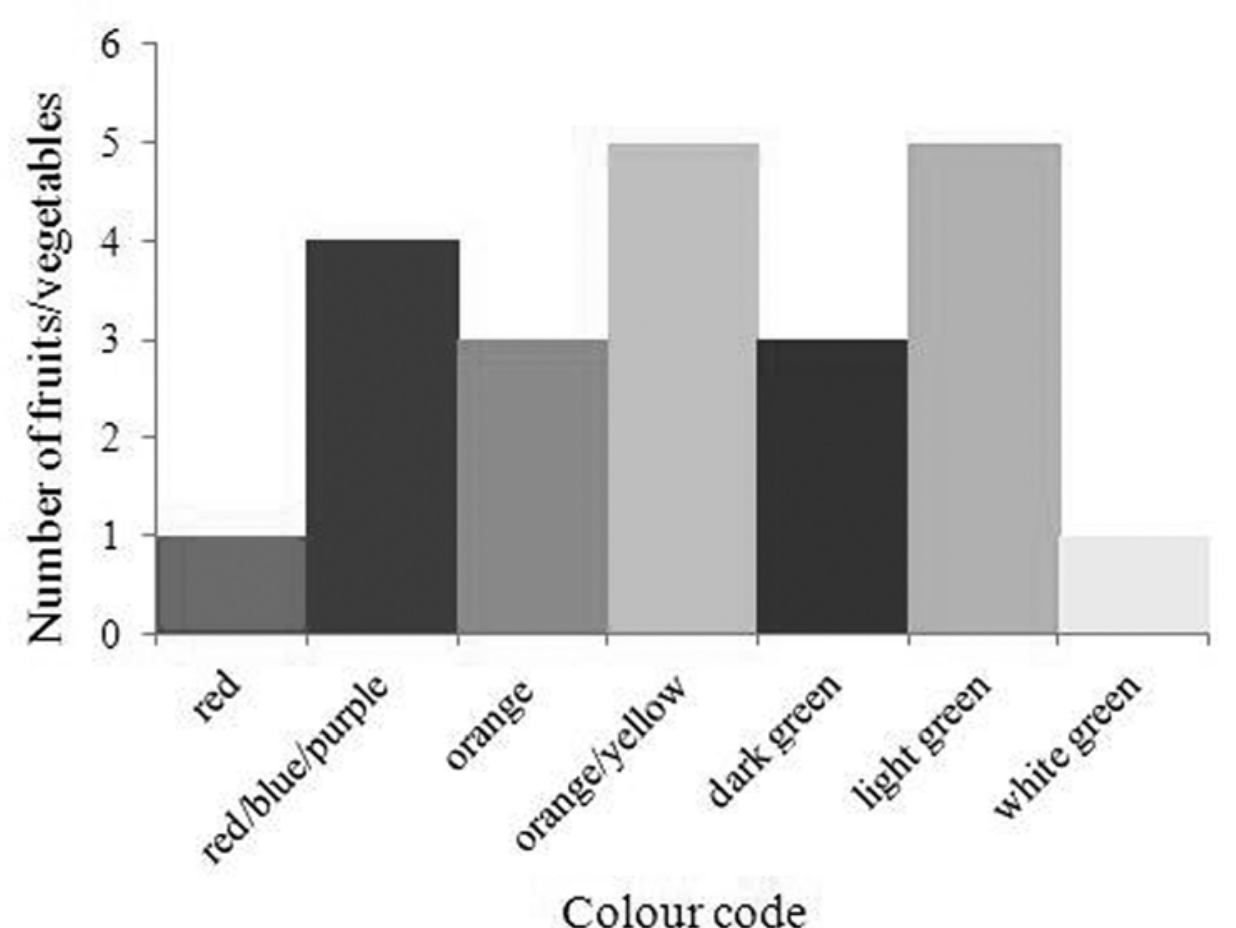

Figure 3 Colour groups of the 22 most common fruits and vegetables growing in school community gardens (over half of the school gardens grew them).

Not only did most gardens grow nearly all of the colors, they also often grew many different types within a single color. The total number of fruits and vegetables grown in school gardens consisted of one red vegetable (tomato), 34 that were blue/purple/red, six that were orange, 42 that were orange/yellow, 13 that were dark green, 39 that were light green, and five that were white green.

Comparative agro-biodiversity of school community gardens

Despite the importance of school community gardens in terms of health and agro-biodiversity we have been unable to find any equivalent scholarly research quantifying the diversity of 
plants grown in school gardens (Guitart et al., 2012). This highlights an important gap in the community garden literature, but also in studies on the health benefits of agro-biodiversity.

From the very limited data on the plants grown in other community gardens, the school community gardens in Brisbane and the Gold Coast appear to be very diverse with an average of 63 plant types per garden (ranging from 7 to 139 plants). In contrast, Saldivar-Tanaka and Krasny (2004) listed only 77 plant types grown across 20 gardens in New York City, Corlett et al. (2003) listed 76 plant types (ranging from 8 to 47 plants per plot) representing 59 species across 26 plots (total of approx. $5570 \mathrm{~m}^{2}$ ) in a Hmong community garden in Sacramento (California), and Baker (2004) listed 16 plant types across three community gardens in Toronto (Canada). Even when the diversity of the school gardens in this study is compared to that recorded in home gardens, it appears to be high. For example, Bernholt et al. (2009) recorded 116 species representing 50 families among 51 home gardens (total of 4.4 ha) in Niamey (Niger) while Winkler Prins (2002) recorded 98 species among 21 gardens in Para (Brazil) compared to the at least 150 species surveyed here.

\section{Conclusions and research directions}

The estimate of the number of species grown across the Brisbane and Gold Coast school gardens is very conservative, as some plant types reported (pumpkins, potatoes, cherries, etc.) could actually represent several different species. Correspondingly, the agro-biodiversity recorded for the gardens likely under-estimates their actual diversity and consequent potential to boost the nutritional intake of school children by eating different plant varieties or cultivars, as some plant types such as tomatoes, may actually represent many different other 
varieties, which may contain different phytochemical concentrations. More detailed assessments of the species, plant varieties, landraces or cultivars grown in these and other community gardens should be undertaken, but this was beyond the capacity of the current research. Furthermore, studies quantifying the amount and diversity of what is eaten by children who use school gardens, in addition to what is grown, should be assessed, and could use a similar approach (Remans et al., 2011).

The main motivations behind the establishment of most school gardens in this study were education and sustainability - both linked to human health and wellbeing and to a lesser extent the preservation of the natural environment. Almost half of the garden managers mentioned health as a primary motivation for establishing gardens in the study area. Moreover, over half of the schools we surveyed sold their produce in their tuckshop (lunchbars), two-thirds allowed children to take home the food they grew, and almost all of the schools responding to the survey used their garden produce in class for educational purposes. This can be seen as one strategy to reduce the obstacles children face in increasing their fruit and vegetable intake (O'Dea, 2003), and corroborates a study in the UK which found that stocking fruit in school tuck shops was an effective strategy for increasing children's fruit consumption (Moore et al., 2000). In this respect, findings from our study confirm those of other Australian studies, which have found links between health and community gardening. In a community garden in Port Melbourne for example, members universally described community gardening as beneficial to their health and well being (Kingsley et al., 2009).

The color classification system of fruits and vegetables used in this study indicates that food plants grown in school community gardens are highly diverse. Unfortunately it was beyond 
the scope of this study to assess whether this diversity of fruits and vegetables grown is directly reflected in school children's education about, and access to, a wide range of different vitamins, minerals, and phytochemicals, but garden managers reported that all of the gardens are used in teaching nutrition and science as part of the school curriculum. A related and tantalizing finding is the presence of traditional bush-tucker foods in these gardens. These food plants may be a good indicator of enhanced nutrition education, and could play a role in addressing the trend of indigenous peoples moving to westernized diets, albeit on a small scale. We found that the schools we surveyed were culturally diverse, including the presence of indigenous students. Our research corroborates growing evidence from international studies which assert that school community gardens could offer an innovative public health intervention model for increasing children's knowledge of, and access to, different types of health-giving fruits and vegetables (e.g. Heim et al., 2011).

Previous research has shown that children's improved knowledge of fruits and vegetables enhances their consumption of these food-plants (Morris and Zidenberg-Cherr, 2002; Somerset et al., 2005). Just half an hour in the garden per week may be sufficient to improve children's ability to identify fruit and vegetables and thus increase their willingness to eat new fruits and vegetables (Cason, 1999). We found that almost two thirds of schools allowed children to take home the food that they grew in the school gardens. School-based community gardens therefore have potential not only to conserve agro-biodiversity but to also positively influence the diets of urban school children (and their families), and to improve their health and wellbeing, thus counteracting some of the negative impacts of rapid urbanization (Blair et al., 1991; Heim et al., 2009). Future research should investigate whether the patterns we have found in this study also apply to other school gardens in other 
cities, for private as well as public schools, and in different climatic zones. And it would be useful to assess whether other types of community gardens may also be positively contributing to the nutrition of urban gardeners.

From what we have found here, it seems likely that school and community gardens could represent an affordable and practical way of improving the health of city dwellers, especially children. Community gardens can potentially be rapidly implemented in any city where there is sufficient space for a small garden, including rooftops, railway verges, abandoned sites where soil contamination is low, harbor fronts, and even in raised garden beds in public plazas. We have found that in South East Queensland, local and state governments are favorably disposed to such urban green-spaces and that philanthropic foundations seem prepared to contribute funding for their establishment. Future research would do well to assess the disposition of urban planners and policy makers to using these highly beneficial urban green-spaces as public health interventions. 


\section{References}

Alaimo, K., Packnett, E., Miles, R., Kruger, D., 2008. Fruit and vegetable intake among urban community gardeners. Journal of Nutrition Education and Behaviour 40, 94101.

Allen, J.O., Alaimo, K., Elam, D., Perry, E., 2008. Growing vegetables and values: benefits of neighborhood-based community gardens for youth development and nutrition. Journal of Hunger and Environmental Nutrition 3, 418-439.

Armstrong, D., 2000. A survey of community gardens in upstate New York: implications for health promotion and community development. Health and Place 6, 319-327.

Australian Bureau of Statistics (ABS), 2009. Children who are overweight or obese. Australian Bureau of Statistics, Canberra.

Australian Bureau of Statistics (ABS), 2011. Regional Population Growth, Population Estimates by Local Government Area, 2001 to 2010. Australian Beaureau of Statistics, Canberra.

Baker, L., 2004. Tending cultural landscapes and food citizenship in Toronto's community gardens. Geographical Review 94, 305-325.

Bernholt, H., Kehlenbeck, K., Gebauer, J., Buerkert, A., 2009. Plant species richness and diversity in urban and peri-urban gardens of Niamey, Niger. Agroforestry Systems 77, 159-179.

Birky, J., Strom, E., 2013. Urban perennials: how diversification has created a sustainable community garden movement in The United States. Urban Geography DOI: 10.1080/02723638.2013.784086, 1-24.

Blair, D., 2009. The child in the garden: an evaluative review of the benefits of school gardening. The Journal of Environmental Education 40, 15-38.

Blair, D., Giesecke, C., Sherman, S., 1991. A dietary, social and economic evaluation of the Philadelphia urban gardening project. The Journal of Nutrition Education 23, 161167.

Blazey, C., Varkulevicius, J., 2006. The Australian fruit and vegetable garden: grow the best fruit and vegetables for good health and flavour. The Digger's Club, Dromana. 
Block, K., Gibbs, L., Staiger, P.K., Gold, L., Johnson, B., Macfarlane, S., Long, C., Townsend, M., 2012. Growing community: the Impact of the Stephanie Alexander Kitchen Garden Program on the social and learning environment in primary schools. Health Education and Behavior 39, 419-432.

Broadway, M.J., Broadway, J.M., 2011. Green Dreams: promoting urban agriculture and the availability of locally produced food in the Vancouver metropolitan area. Focus on Geography 54, 33-41.

Byrne, J., Sipe, N., Searle, G., 2010. Green around the gills? The challenge of density for urban greenspace planning in SEQ. Australian Planner 47, 162-177.

Cameron, A., Welborn, T., Zimmet, P., Dunstan, D., Owen, N., Salmon, J., Dalton, M., Jolley, D., Shaw, J., 2003. Overweight and obesity in Australia: the 1999-2000 Australian diabetes, obesity and lifestyle study (AusDiab). Medical Journal of Australia 178, 427-432.

Campbell, M., 2004. Building a common table: the role for planning in community food systems. Journal of Planning Education and Research, 341-355.

Canaris, I., 1995. Growing foods for growing minds: integrating gardening and nutrition education into the total curriculum. Children's Environments 12, 134-142.

Cason, K.L., 1999. Children are "growing healthy" in South Carolina. Journal of Nutrition Education 31, 235-236.

Chomitz, V.R., McGowan, R.J., Wendel, J.M., Williams, S.A., Cabral, H.J., King, S.E., Olcott, D.B., Cappello, M., Breen, S., Hacker, K.A., 2010. Healthy Living Cambridge Kids: a community-based participatory effort to promote healthy weight and fitness. Obesity 18, S45-S53.

Clement, M., 2010. Urbanization and the natural environment: an environmental sociological review and synthesis. Organization and Environment 23, 291.

Corkery, L., 2004. Community gardens as a platform for education for sustainability. Australian Journal of Environmental Education 20, 61-75.

Corlett, J., Dean, E., Grivetti, L., 2003. Hmong gardens: botanical diversity in an urban setting. Economic Botany 57, 365-379. 
Department of Health and Ageing, 2007. Australian National Children’s Nutrition and Physical Activity Survey: Main findings. Commonwealth of Australia, Canberra.

Domene, E., Sauri, D., 2007. Urbanization and class-produced natures: vegetable gardens in the Barcelona Metropolitan Region. Geoforum 38, 287-298.

Eigenbrod, F., Bell, V., Davies, H., Heinemeyer, A., Armsworth, P., Gaston, K., 2011. The impact of projected increases in urbanization on ecosystem services. Proceedings of the Royal Society B: Biological Sciences 278, 3201-3208.

Graham, H., Beall, D.L., Lussier, M., McLaughlin, P., Zidenberg-Cherr, S., 2005. Use of school gardens in academic instruction. Journal of Nutrition Education and Behavior 37, 147-151.

Groenewegen, P.P., Van Den Berg, A.E., De Vries, S., Verheij, R.A., 2006. Vitamin G: effects of green space on health, well-being, and social safety. BMC Public Health 6, 149-158.

Guitart, D.A., Pickering, C.M., Byrne, J., 2012. Past Results and future directions in urban communtiy gardens research. Urban Forestry and Urban Greening 11, 364-373.

Harris, E. (2009). "The role of community gardens in creating healthy communities." Australian Planner 46(2): 24-27.

Heber, D., Bowerman, S., 2001. Applying science to changing dietary patterns. The Journal of Nutrition 131, 3078S-3081S.

Heim, S., Stang, J., Ireland, M., 2009. A garden pilot project enhances fruit and vegetable consumption among children. Journal of the American Dietetic Association 109, 1220-1226.

Heim, S., Bauer, K.W., Stang, J., Ireland, M., 2011. Can a community-based intervention improve the home food environment? parental perspectives of the influence of the delicious and nutritious garden. Journal of Nutrition Education and Behavior 43, 130 134.

Henryks, J., 2011. Changing the menu: rediscovering ingredients for a successful volunteer experience in school kitchen gardens. Local Environment 16, 569-583. 
Hutcheon, T., 2011. Submission to aid in the development of a National Food Plan. Queensland Conservation, Brisbane, p. 9.

Jamison, J.R., 2003. Dietary diversity: a case study of fruit and vegetable consumption by chiropractic patients. Journal of Manipulative and Physiological Therapeutics 26, 383-389.

Kameshiwari, P., Kaufman, J., 1999. Placing the food system on the urban agenda: the role of municipal institutions in food systems planning. Agriculture and Human Values 16, 213-224.

Kaplan, R. 1973, Some psychological benefits of gardening, Environment and Behavior, 5, $145-161$.

Kingsley, J., Townsend, M., Henderson-Wilson, C., 2009. Cultivating health and wellbeing: members' perceptions of the health benefits of a Port Melbourne community garden. Leisure Studies 28, 207-219.

Kitchen Garden Foundation (KGF), 2013. About Us: Stephanie Alexander Kitchen Garden Foundation, http://www.kitchengardenfoundation.org.au/about/about-us, accessed: 25/11/2013.

Larder, N., Lyons, K., Woolcock, G., 2012. Enacting food sovereignty: values and meanings in the act of domestic food production in urban Australia. Local Environment, DOI: 10.1080/13549839.2012.716409,1-21.

Lineberger, S.E., Zajicek, J.M., 2000. School gardens: can a hands-on teaching tool affect students' attitudes and behaviors regarding fruit and vegetables? HortTechnology 10, 593-597.

Lund, E., 2003. Non-nutritive bioactive constituents of plants: dietary sources and health benefits of glucosinolates. International Journal for Vitamin and Nutrition Research 73, 135.

Magarey, A., Daniels, L.A., Smith, A., 2001. Fruit and vegetable intakes of Australians aged 2-18 years: an evaluation of the 1995 National Nutrition Survey data. Australian and New Zealand Journal of Public Health 25, 155-161. 
McAleese, J.D. and Rankin, L.L., 2007, Garden based nutrition education affects fruit and vegetable consumption in sixth-grade adolescents. Journal of the American Dietetic Association, 107, 662-665.

McFarlane, A., 2008. Successful gardening in warm climates: a new edition of the bestselling guide to waterwise gardening and organic growing. ABC Books, Sydney.

Moore, L., Paisley, C.M., Dennehy, A., 2000. Are fruit tuck shops in primary schools effective in increasing pupils' fruit consumption? A randomised controlled trial. Nutrition and Food Science 30, 35-39.

Morris, J., Zidenberg-Cherr, S., 2002. Garden-enhanced nutrition curriculum improves fourth-grade school children's knowledge of nutrition and preferences for some vegetables. Journal of the American Dietetic Association 102, 91-93.

O'Dea, J., 2003. Why do kids eat healthful food? Perceived benefits of and barriers to healthful eating and physical activity among children and adolescents. Journal of the American Dietetic Association 103, 497-501.

Oakman, H., 1975. Tropical and subtropical gardening. Jacaranda Press, Milton.

Ozer, E.J., 2007. The effects of school gardens on students and schools: Conceptualization and considerations for maximizing healthy development. Health Education \& Behavior 34, 846-863.

Pauleit, S., Ennos, R., Golding, Y., 2005. Modeling the environmental impacts of urban land use and land cover change-a study in Merseyside, UK. Landscape and Urban Planning 71, 295-310.

Perrin, A., Simon, C., Hedelin, G., Arveiler, D., Schaffer, P., Schlienger, J., 2002. Ten-year trends of dietary intake in a middle-aged French population: relationship with educational level. European Journal of Clinical Nutrition 56, 393-401.

Pires, V., Burton, P., 2013. Help or hindrance? The relationship between land use planning and urban agriculture on the Gold Coast, in: Farmar-Bowers, Q., Higgins, V., Millar, J. (Eds.), Food Security in Australia. Springer, Dordrecht, pp. 381-396.

Popkin, B.M., 1999. Urbanization, lifestyle changes and the nutrition transition. World Development 27, 1905-1916. 
Pothukuchi, K., Kaufman, J.L., 1999. Placing the food system on the urban agenda: the role of municipal institutions in food systems planning. Agriculture and Human Values 16, 213-224.

Queensland Govrnment, 2011. Overweight and Obesity Fact Sheet, 2011. Population Epidemiology Unit, Division of the Chief Health Officer, Queensland Health, Brisbane, <www.health.qld.gov.au/epidemiology/documents/overweight-2011-fs.pdf > accessed September 24, 2013.

Ratcliffe, M.M., Merrigan, K.A., Rogers, B.L., Goldberg, J.P., 2011. The effects of school garden experiences on middle school-aged students' knowledge, attitudes, and behaviors associated with vegetable consumption. Health Promotion Practice 12, 3643.

Remans, R., Flynn, D.F.B., DeClerck, F., Diru, W., Fanzo, J., Gaynor, K., Lambrecht, I., Mudiope, J., Mutuo, P.K., Nkhoma, P., 2011. Assessing nutritional diversity of cropping systems in African villages. PLoS ONE 6, e21235.

Saldivar-Tanaka, L., Krasny, M., 2004. Culturing community development, neighborhood open space, and civic agriculture: the case of Latino community gardens in New York City. Agriculture and Human Values 21, 399-412.

Sanigorski, A.M., Bell, A.C., Swinburn, B.A., 2007. Association of key foods and beverages with obesity in Australian school children. Public Health Nutrition 10, 152-157.

Somerset, S., Ball, R., Flett, M., Geissman, R., 2005. School-based community gardens: reestablishing healthy relationships with food. Journal of the Home Economics Institute of Australia 12, 25-33.

Stables, G., Subar, A., Patterson, B., Dodd, K., Heimendinger, J., Van, D., Anns, M., Nebeling, L., 2002. Changes in vegetable and fruit consumption and awareness among US adults: results of the 1991 and 1997 5-a-day for better health program surveys. Journal of the American Dietetic Association 102, 809-817.

Teig, E., Amulya, J., Bardwell, L., Buchenau, M., Marshall, J., Jill, S., 2009. Collective efficacy in Denver, Colorado: Strengthening neighbourhoods and health through community gardens. Health and Place 15, 1115-1122. 
Timperio, A., Ball, K., Roberts, R., Campbell, K., Andrianopoulos, N., Crawford, D., 2008. Children's fruit and vegetable intake: associations with the neighbourhood food environment. Preventive Medicine 46, 331-335.

Turner, B., Henryks, J., Pearson, D., 2011. Community gardens: sustainability, health and inclusion in the city. Local Environment 16, 489-492.

Van Duyn, M.A., Pivonka, E., 2000. Overview of the health benefits of fruit and vegetable consumption for the dietetics professional: selected literature. Journal of the American Dietetic Association 100, 1511-1521.

Vaughan, J.G., Geissler, C., 2009. The New Oxford Book of Food Plants. Oxford University Press, New York.

Wakefield, S., Yeudall, F., Taron, C., Reynolds, J., Skinner, A., 2007. Growing urban health: Community gardening in South-East Toronto. Health Promotion International 22, 92101.

WinklerPrins, A.M.G.A., 2002. House-lot gardens in Santarém, Pará, Brazil: linking rural with urban. Urban Ecosystems 6, 43-65.

Wu, Y., Zhang, X., Shen, L., 2011. The impact of urbanization policy on land use change: a scenario analysis. Cities 28, 147-159.

Yao, L.H., Jiang, Y., Shi, J., Tomas-Barberan, F., Datta, N., Singanusong, R., Chen, S., 2004. Flavonoids in food and their health benefits. Plant Foods for Human Nutrition 59, 113-122.

Zaradic, P., Pergams, O., Kareiva, P., Somers, M., 2009. The impact of nature experience on willingness to support conservation. PLoS ONE 4, e7367. 
Table 2. Use of school gardens in the school curriculum and management of garden produce

\begin{tabular}{|c|c|c|c|c|c|c|c|}
\hline $\begin{array}{l}\text { School ID } \\
(\mathrm{n}=23)\end{array}$ & $\begin{array}{l}\text { Nutrition in } \\
\text { curriculum (n=22) }\end{array}$ & $\begin{array}{l}\text { Used in } \\
\text { teaching } \\
(\mathrm{n}=22)\end{array}$ & $\begin{array}{l}\text { Students take } \\
\text { produce home } \\
(\mathrm{n}=21)\end{array}$ & $\begin{array}{l}\text { Produce sold to } \\
\text { staff/students } \\
(\mathrm{n}=21)\end{array}$ & $\begin{array}{l}\text { Produce used in } \\
\text { tuck shop }(\mathrm{n}=21)\end{array}$ & $\begin{array}{l}\text { Produce cooked in } \\
\text { teaching kitchen } \\
(\mathrm{n}=20)\end{array}$ & $\begin{array}{l}\text { Surplus produced } \\
(\mathrm{n}=21)\end{array}$ \\
\hline B1 & 1 & 1 & 0 & 0 & 0 & 0 & 0 \\
\hline B2 & 1 & 1 & 1 & 0 & 1 & 1 & 1 \\
\hline B3 & 1 & 1 & 1 & 0 & 1 & 1 & 1 \\
\hline B4 & 1 & 1 & 1 & 0 & 1 & 0 & 0 \\
\hline B5 & 1 & 1 & 1 & 0 & 1 & 0 & 1 \\
\hline B6 & 1 & 1 & 1 & 0 & 0 & 1 & 0 \\
\hline B7 & 1 & 1 & 1 & 0 & 0 & 0 & 0 \\
\hline B8 & 1 & 1 & 1 & 1 & 1 & 1 & 1 \\
\hline B9 & 1 & 1 & 1 & 0 & 1 & 0 & 0 \\
\hline B10 & 1 & 1 & 1 & 0 & 0 & 1 & 0 \\
\hline B11 & 1 & 1 & 1 & 0 & 0 & 0 & 0 \\
\hline B12 & 1 & 1 & & 1 & & 1 & 1 \\
\hline B13 & 1 & 1 & 1 & 0 & 0 & 0 & 1 \\
\hline B14 & 1 & 1 & 0 & 1 & 1 & 0 & 0 \\
\hline B15 & 0 & 0 & 0 & 0 & 0 & 0 & 0 \\
\hline B16 & 1 & 1 & 1 & 1 & 1 & 0 & 1 \\
\hline B17 & 1 & 0 & 0 & & 0 & & 1 \\
\hline GC1 & 1 & 1 & 1 & 0 & 0 & 0 & 1 \\
\hline \multicolumn{8}{|l|}{ GC2 } \\
\hline GC3 & 1 & 1 & 0 & 0 & 1 & 1 & 1 \\
\hline GC4 & 1 & 1 & 0 & 1 & 1 & 0 & 0 \\
\hline GC5 & 1 & 1 & 1 & & 0 & & \\
\hline GC6 & 1 & 1 & 0 & 0 & 1 & 1 & 0 \\
\hline $\begin{array}{l}\text { Total } \\
\text { \% all school }\end{array}$ & 21 & 20 & 14 & 5 & 11 & 8 & 10 \\
\hline gardens & $91.30 \%$ & $86.96 \%$ & $60.87 \%$ & $21.74 \%$ & $47.83 \%$ & $34.78 \%$ & $43.48 \%$ \\
\hline \% responded & $95.45 \%$ & $90.91 \%$ & $66.67 \%$ & $25.00 \%$ & $52.38 \%$ & $40.00 \%$ & $47.62 \%$ \\
\hline
\end{tabular}

Notes: Blank denotes a non-response; 0 denotes a negative response. B = Brisbane, GC = Gold Coast. 